DOI: $10.15421 / 272007$

УДК 621.039 (09):629.76(09)

Г. Л. Звонкова

ДУ «ІДНТПІН ім. Г. М. Доброва НАН України», Київ, Украӥна

\title{
ВНЕСОК АКАДЕМІЧНОЇ НАУКИ УКРАЇНИ В ЯДЕРНУ, РАКЕТНУ І КОСМІЧНУ ГАЛУЗІ: ФРАГМЕНТИ ІСТОРІї
}

E-mail: zvonkova@ukr.net

ORCID ID: https://orcid.org/0000-0003-4029-8721

Анотація. Висвітлено внесок вчених Академії наук України в організацію ядернофізичних досліджень в різних суспільно-історичних умовах розвитку країни. Проаналізовано конкретні розробки в ядерній, ракетній та космічній галузях вчених інститутів НАН України на тлі світових досягнень. Показано форми наукової роботи в Академії наук, взаємодія роботи інститутів та лабораторій, які починали створюватися в державі. Акцентовано увагу на внеску конкретних вчених у розгортання і впровадження результатів досліджень. Зроблено спробу висвітлити деякі аспекти роботи Українського Фізико-Технічного Інституту, показано роль конкретних вчених у розгортанні широкого спектра ядерно-фізичних досліджень. Зроблено акцент на тому, що завдяки плідній діяльності вчених академічних інститутів та лабораторій були отримані вагомі наукові результати, які сприяли розвитку багатьох галузей і держави в цілому.

Ключові слова: Академія наук, інститут, наукові кадри, розробка, програма досліджень, ЕОМ.

\section{G. L. Zvonkova}

\section{Dobrov Institute for Scientific and Technologscal Potential and Science History Studies} of the NAS of Ukraine

\section{CONTRIBUTION OF THE ACADEMIC SCIENCE OF UKRAINE IN THE NUCLEAR, MISSILE AND SPACE INDUSTRY: FRAGMENTS OF HISTORY}

\begin{abstract}
The contribution of scientists of the Academy of Sciences of Ukraine to the organization of nuclear-physical research in various socio-historical conditions of the country's development is highlighted. Concrete developments in the nuclear, missile and space industries of NAS of Ukraine scientists against the background of world achievements are analyzed. The forms of scientific work in the Academy of Sciences, the interaction of the institutes and laboratories that began to be created in the state are shown. Emphasis on the contribution of special scientists to the development and implementation of research results is made. An attempt to uncover some aspects of the work of the Ukrainian Institute of Physics and Technology, the role of definite scientists in the development of a wide range of nuclear-physical studies is shown. The article emphasizes that due to the productive activity of scientists of academic institutes and laboratories significant scientific results have been obtained. They have contributed to the development of many industries and the state in total.
\end{abstract}


An attempt to uncover the beginning of the development of measuring radiation technology has been made. Starting from the organization of Ukrainian Physical and Technical Institute, the works on the creation of an All-Union cryogenic laboratory such as Leiden, where powerful installations for the extraction of liquid air, hydrogen and helium were planned have begun. It was the fourth laboratory in the world after laboratories in Leiden, Toronto and Berlin. In 1930, a liquid air machine was installed here.

The introduction of nuclear power plants on the territory of Ukraine and the requirements to improve the safety of their work dictated by the necessity to intensify scientific researches. Results of scientific activity of scientists of the Institute of Nuclear Research are shown. Achievements of cooperation of scientists of the Institute of Nuclear Research with colleagues from the Institute of Materials Science of the USSR Academy of Sciences are analyzed. It was emphasized that a number of arrangements were taken by the People's Commissariat of the Ukrainian SSR, the Academy of Sciences of the Ukrainian SSR, and the party organisations. It made possible to renew activity at the Ukrainian Physical and Technical Institute, training of personnel, and to engage scientific institutions and specialists to the work on the using of nuclear energy.

Keywords: Akademy of Sciences, institute, scientific staff, development, research program, EC.

Вступ. Ядерно-фізичні дослідження в Україні вперше розпочались у фізикотехнічному інституті (УФТІ, згодом ХФТІ), створеному у Харкові за ініціативи А. Ф. Йоффе. У 1929 р. до штату інституту входили 5 науковців-харків'ян: професори А. В. Желеховський, Д. С. Штейнберг, А. О. Слуцкін, М. Ю. Помазанов і М. І. Дорогой; ленінградські вчені К. Д. Синельников, О. І. Лейпунський - всього 9 науковців. Консультантами зараховано Д. А. Рожанського, Г. А. Гамова, П. Л. Капицю, який в той час працював у Кембриджі (Англія), та П. С. Еренфеста (Голландія, Лейден). Основними напрямками роботи УФТІ стали: фізика ядра, фізика надвисоких частот, фізика низьких температур і фізика кристалів. В УФТІ розпочав свої піонерські роботи талановитий теоретик-дослідник, майбутній лауреат Нобелівської премії Л.

Д. Ландау. Тут з 1932 до 1937 р. він очолював відділ теоретичної фізики і створив «школу Ландау» [1, с. 43-44].

Матеріал і методи досліджень. У статті застосовано метод джерелознавчого аналізу. Джерельну базу дослідження склали матеріали фондів ЦДАВОВ України та Державного архіву Київської області.

Результати та обговорення. Для підготовки кадрів у 1930 p. в Харківському механіко-машинобудівному інституті професор I. М. Бабаков разом 3 ученими УФТІ організував фізико-механічний факультет - перший факультет такого типу в Радянському Союзі. Участь у його створенні брали науковці О. І. Лейпунський, Д. Д. Іваненко, Л. В. Розенкевич, Л. М. П'ятигорський та ін. Того самого року до викладацької роботи стали І. В. Обреїмов, К. Д. Синельников, А. К. Вальтер. Першим деканом факультету став I. В. Обреїмов [2, с. 81].

3 початку організації УФТІ почались роботи зі створення Всесоюзної кріогенної лабораторії на зразок Лейденської, яка мала би потужні установки для добування рідких повітря, водню та гелію. Вона стала четвертою лабораторією у світі після лабораторій у Лейдені, Торонто і Берліні. У 1930 р. тут була встановлена машина рідкого повітря. 1930 р. Л. В. Шубников почав тут працювати разом 3 В. С. Горським, М. О. Бріліантовим, А. Ф. Прихотько та ін. 31931 р. кріогенна 
лабораторія була обладнана двома водневими машинами з Голландії, більша 3 них давала 12 літрів рідкого повітря на годину. Так вперше в СРСР було започатковано дослідження в галузі фізики конденсованого стану, фізики і техніки низьких температур [3, с. 177-179; 4, с. 14].

У 1932 р. так звана «високовольтна бригада» УФТІ вперше у світі повторила дослід англійських учених Дж. Кокфорта i Е. Уолтона. Учні Е. Резерфорда К. Д. Синельников, О. І. Лейпунський, А. К. Вальтер і Г. Д. Латишев здійснили штучне розщеплення ядер літію під дією прискорених протонів [4, с. $120 ; 5$, с. 3].

У 1935 р. у Харкові німецький фізик Ф. Ф. Ланге зайнявся розробкою променевої зброї дією на 500-1000 метрів. Він збудував найбільший на той час у світі генератор Маркса на напругу 5 млн. вольт. 27 лютого 1939 р. Комісія 3 атомного ядра Відділення фізико-математичних наук АН СРС, надаючи важливого значення наявності в УФТІ імпульсного генератора, прийняла постанову про залучення інституту до вирішення проблем урану [6, с. 108, 110-111].

Напередодні війни, коли реальністю стала ланцюгова реакція поділу урану, науковцями було піднято питання про будівництво в УФТІ циклотрона. Харківські вчені В. А. Маслов, В. С. Шпінель і Ф. Ф. Ланге подали заявку в АН СРСР на винахід атомної бомби під назвою «Про використання урану як вибухової та отруйної речовини». Негативний відгук на їх заявку як на фантастичну ідею дали Уранова комісія і Радієвий інститут (підписи академіків В. Г. Хлопіна, П. Л. Капиці, А. Ф. Йоффе), а також Наркомат СРСР. Автори заявки надсилають листи в АН СРСР і Уранову комісію з інформацією про результати досліджень і викладенням «Способу виготовлення уранової суміші, збагаченої ураном з масовим числом 235. Багатокамерна центрифуга». Знову отримано негативний висновок як на неперспективну пропозицію для військово-промислової справи, яка не має практичного значення для оборонної цілі. Такий самий висновок отримано на лист В. А. Маслова (лютий 1941 р.), адресований Наркому оборони СРСР, «Про необхідність організації робіт по використанню атомної енергії у військових цілях». В. С. Шпінель у 2001 р. заявив, «що якби фізикам Харкова у 1939-1940 рр. були надані такі ж можливості, які потім мав I. В. Курчатов, то Радянський Союз міг би отримати атомну бомбу ще у 1945 р.» [5, с. 4, 18-47; 7, с. 370-386].

Ситуація змінилась тоді, коли 328 вересня 1942 р. Державний Комітет Оборони СРСР прийняв розпорядження «Про організацію робіт по урану». В розпорядженні підкреслювалася необхідність купівлі циклотронної лабораторії у США. Протягом наступних років з боку Народного Комісаріату СРСР, АН УРСР, партійних органів було прийнято ряд заходів 3 поновлення робіт в УФТІ, підготовки кадрів, залучення до участі в роботах по використанню внутрішньоядерної енергії наукових установ і спеціалістів. 2 березня 1946 р. Рада Народних Комісарів СРСР за підписом Й. В. Сталіна прийняла постанову «Про організацію Лабораторії № 1 при Харківському фізико-технічному інституті Академії наук Української РСР». Нею було визначено програму досліджень 3 ядерної фізики і напрямки реалізації результатів у атомній енергетиці. Вся друга половина планів НДР у Лабораторії № 1 була підпорядкована виконанню цього розпорядження [8, с. 47-93].

У 1956 р. після закінчення Московського державного університету у ХФТІ почав працювати О. О. Лаврентьєв. Незалежно від академіка В. Л. Гінзбурга він запропонував дейтерід літія-6 як вибухову речовину для термоядерних зарядів. Незалежно від академіків I. Є. Тамма і А. Д. Сахарова О. О. Лаврентьєв висунув 
ідею керованого термоядерного синтезу, засновану на термоізоляції плазми силовим полем. У 1951 р. О. О. Лаврентьєв запропонував пастку для утримання високотемпературної плазми комбінованим електричним і магнітним полями [8, с. $210 ; 9$, c. 62].

3 початку 1950-х рр. в УФТІ почала формуватися наукова школа фізиківтеоретиків під керівництвом О. I. Ахієзера, одного 3 найближчих учнів Л. Д. Ландау. Її представниками стали понад 20 науковців-дослідників: академіки АН України В. Г. Бар'яхтар, Д. В. Волков, С. В. Пелітминський, А. Г. Ситенко, Я Б. Фрайнберг, член-кореспондент АН України П. І. Фомін та інші. 3 середини 1960-х рр. почав стрімко зростати внесок школи в ядерну, ракетну, космічну галузі. 1960-1980-і рр. стали періодом наукового і технічного підйому ХФТІ. Наукові здобутки були пов'язані 3 іменами К. Д Синельникова і його найближчими соратниками А. К. Вальтером, Б. Г. Лазарєвим, О. І. Ахієзером, В. С. Івановим, ученими відомих наукових шкіл О. І. Ахієзера, Я. Б Файнберга, Д. В. Волкова, С. В. Пелетминського, К. М. Степанова, І. М. Неклюдова, М. Ф. Шульги. Інститут почав працювати над розробкою, виготовленням і випробуванням нових зразків воєнної техніки. Тут розпочались роботи зі створення зброї космічного базування в рамках програми «Звездные войны». Інститут був єдиним в Україні центром термоядерних досліджень з сучасною експериментальною базою і залучений до участі в Урановій і Аерокосмічній Державних програмах Радянського Союзу. Наукова програма під назвою «Україна» передбачала розробку основ керованого термоядерного реактора. Виконання основних етапів цієї програми було завершено в кінці 1980-х рр. При цьому Україна увійшла в сімку країн світу, які розробляють проблему керування термоядерними реакціями. Так в Україні розпочалась «термоядерна ера» [4, с. 27-28, 59, 61; 9, с. 42-43; 10, с. 501-504].

Теоретичні і експериментальні дослідження взаємодії заряджених часток $\mathrm{i}$ нейтронів з ядрами, що розпочаті в УФТІ на початку 1930-х pp., у 1944 р. за ініціативи академіка О.І. Лейпунського продовжені в Інституті фізики АН України (Київ). Під його керівництвом досягнуто значних успіхів у вирішенні умов здійснення ланцюгової реакції поділу ядер урану та оцінено енергію, яка при цьому виділяється. У 1950-1960-х рр. створено експериментальну базу, за допомогою якої досліджувались ядерні реакції. Для виконання накреслених робіт послідовно було введено в дію: у 1956 р. - циклотрон У-120; у 1960 р. - дослідницький реактор BВР-М; у 1964 р. - електростатичний генератор ЕГП-5. Потреби в розвитку ядернофізичних досліджень обумовили необхідність комплексного вирішення ряду пов'язаних 3 цим проблем. Для цього у 1970 р. Президія АН УРСР за ініціативою академіка М. В. Пасічника прийняла постанову про створення Інституту ядерних досліджень (ІЯД) [11, с. 5-6; 12, с. 3-4].

Паралельно зі згаданим в Україні розвивався напрямок створення вимірювальної радіаційної техніки. У 1962 р. у Києві, Дніпропетровську, Донецьку, Вінниці, Одесі, Ворошиловграді і м. Сокаль Львівської області було створено ряд територіальних базових ізотопних лабораторій (БІЛ). Радіаційні апарати лабораторій дозволяли проводити безконтактний контроль i регулювати технологічні процеси; забезпечували отримання значного економічного ефекту; скоротили чисельність персоналу на шкідливих для здоров'я працівників роботах при вимірах рівнів радіації. У 1966 р. БІЛ республіки були передані у підпорядкування міністерств Москви. Рада Міністрів УРСР заперечувала доцільність передачі БІЛ з республіки, оскільки це привело б до різкого скорочення робіт, які виконувалися на шахтах і збагачувальних фабриках. Недоцільність 
передачі БІЛ в управління Центру Ради Міністрів республіки була обгрунтована і тим, що БІЛ, які працювали в Україні, експлуатували переважну кількість усієї радіоізотопної техніки Міністерства вугільної промисловості СРСР, вели ії монтаж на шахтах Ростовській області і «Воркутавугілля» [13, ф. Р-2, оп. 13, спр. 6613, арк. 97, 107, 108].

Введення до дії АЕС на території України і вимоги поліпшення безпеки їх роботи диктували необхідність інтенсифікації наукових досліджень вченими Інституту ядерних досліджень (ІЯД). У 1976 р. його співробітниками спільно 3 Інститутом матеріалознавства АН УРСР визначено радіаційний ресурс сталі 12ХГНМ. На основі результатів видано дані для проектування і конструювання корпусу реактора АЕC [13, ф. Р-2, оп. 14, спр. 262, арк. 93].

Унікальним досягненням світового рівня стало створення і освоєння в ІЯД ізохронного циклотрона У-240. На цій установці і на прискорювачі У-120 створено вимірювальні центри, оснащені сучасними ЕОМ. Під науковим керівництвом чл.-кор. АН УРСР В.М. Струтинського на циклотроні У-240 почали проводити глибокі дослідження теорії ядра. Наслідком цієї роботи стало якісно нове уявлення структури ядра і фізики тисків. За відкриття нового явища - просвітлення хвильового бар'єра Л. І. Романюк, В. В. Лісіченко і Н. С. Свавільський отримали Державну премію в галузі науки і техніки [13, ф. Р-2, оп. 14, спр. 263, т. 3, арк. 25; 14, ф. П10488, оп. 1, спр. 46, арк. 30, 36-37].

3 метою підвищення ефективності впровадження наукових розробок в народне господарство у 1976 р. створено Ужгородське відділення ІЯД. Тут провадилися дослідження зі взаємодії нейтронів з радіоактивними ядрами і ядрами елементів конструктивних матеріалів ядерних реакторів. Створено оригінальні надійні прилади контролю за розвитком ланцюгової реакції, а також прилади широкого застосування на енергетичних об'єктах Вірменської, Ново-Воронезької і Чорнобильської АЕС [14, ф. П10488, оп. 1, спр. 46, арк. 13-14, 25$].$

В 1951 р. під науковим керівництвом С.О. Лебедєва в Інституті електротехніки АН УРСР створено першу в континентальній Європі ЕОМ («МЭСМ»). Машина значно відрізнялась у кращий бік від першої американської лампової ЕОМ «ЕNIAC». За «МЭСМ» з'явилась «БЭСМ» - найпродуктивніша в Європі й одна із найнадійніших у світі. Це був перспективний напрямок, котрий давав змогу СРСР поряд з розвинутими країнами йти ходою НТР [15, с. 335-338].

У 1970-ті pр. в Інституті кібернетики АН УРСР під науковим керівництвом В. М. Глушкова розроблено ЕОМ «Дніпро» - першу в Радянському Союзі напівпровідникову керуючу машину. У 1969 р. дві ЕОМ «Дніпро» керували великим екраном, на якому відтворювались події спільного космічного польоту космонавтів СРСР і США на кораблі «Союз» - «Аполлон». Машина працювала у багатьох соціалістичних країнах [16, с. 16-18].

\section{Висновки}

3 організацією УФТІ почались роботи зі створення Всесоюзної кріогенної лабораторії на зразок Лейденської, яка мала би потужні установки для добування рідких повітря, водню та гелію. Таким чином, на початку 30-х pp. XX ст. в Українському фізико-технічному інституті було розпочато теоретичні i експериментальні дослідження взаємодії заряджених часток і нейтронів 3 ядрами, що обумовило розвиток в Україні ядерно-фізичних досліджень. Паралельно в Україні розвивався напрямок створення вимірювальної радіаційної техніки. 
Створено оригінальні надійні прилади контролю за розвитком ланцюгової реакції, а також прилади широкого застосування на енергетичних об'єктах.

\section{References}

1. Zvonkova, H. L. (2013). Kharkov Institute of Physics and Technology NAS of Ukraine. Visnyk NTU «KhPI». Seriia Istoriia nauky i tekhniky, no 10 (984), pp. 42-50 (in Ukrainian).

2. Breslavskyi, D. V., Larin, A. O. (2007). The origin and development of the system of physics in Ukraine. Nauka ta naukoznavstvo, Kyiv, no 2, pp. 76-82 (in Ukrainian).

3. Shubnykov, L. V. (1990). Selected works. Memories. Kyiv, 352 p. (in Russian).

4. Khramov, Yu. A. (1991). Histoty of formation and development of physical schools in Ukraine. Kyiv, 216 p. (in Russian).

5. Laboratory № 1 and the USSR Atomic project. Documents and materials (2011). Ed. by A. N. Dovbnia, Kharkiv, 370 p. (in Russian).

6. Raniuk, Yu. M. (2002). Two labs by Professor F. Lange, Nauka ta naukoznavstvo. Kyiv. no 1, pp. 108-120.

7. Raniuk, Yu. M. (2001). Laboratory №1. Nuclear Physics in Ukraine. Kharkiv, 558 p. (in Russian).

8. Tolok, V. T, Kohan, V. S., Vlasov, V. V. (2008). Physics and Kharkov. Kharkov, 408 p. (in Russian).

9. Kohan, V. S., Sofronyi, V. V. (2008). UFTI employees are members of the Great Patriotic War. Kharkiv, 320 p. (in Russian).

10. Lazarev, B. H. (2003). Life in science. Selected works. Memories. NNTs KhFTY, $704 \mathrm{p}$.

11. Institute for nuclear research: a handbook. (1981). Compilers A. P. Trofymenko, P. L. Shmaryn. Kyiv, 74 p. (in Russian).

12. Institute of Physics USSR Academy of Science (1979). Compilers M. T. Shpak, V. Y. Melnyk. Kyiv, 118 p. (in Russian).

13. TsDAVOV Ukrainy. f. R-2, inv.13, deed 6613, s. 97, 107, 108.

14. Derzhavnyi arkhiv Kyivskoi oblasti. f. P10488, inv. 1, deed 46, s. 30, 36-37.

15. For Machines to robots (1990). (in 2 books, book 2). Essays about famous inventors, excerpts from documents. scientific articles, memoirs, patent texts. Buck. 2, 414 p. (in Russian).

16. Malynovskyi, B. M. (2001). Known and unknown in the history of information technology in Ukraine. Kyiv, 214 p. (in Ukrainian).

Received 17.01.2020

Accepted 13.02.2020 